\title{
Pengaruh Bauran Pemasaran (Marketing Mix) Terhadap Minat Beli Konsumen di Okui Kopi 3.0 Surabaya
}

\author{
Rizki Ivah Lutfiah $^{1}$, Sri Widayanti ${ }^{2}$, Sri Tjondro Winarno ${ }^{3}$ \\ ${ }^{I}$ Fakultas Pertanian, Universitas Pembangunan Nasional “Veteran” Jawa Timur, Jl. Raya Rungkut Madya, Surabaya, 60294 \\ E-mail: \\ ${ }^{2}$ Fakultas Pertanian, Universitas Pembangunan Nasional “Veteran” Jawa Timur, Jl. Raya Rungkut Madya, Surabaya, 60294 \\ E-mail: - \\ ${ }^{3}$ Fakultas Pertanian, Universitas Pembangunan Nasional “Veteran” Jawa Timur, Jl. Raya Rungkut Madya, Surabaya, 60294 \\ E-mail: sritjondro_w@upnjatim.ac.id
}

\begin{abstract}
The purpose of this study aims to determine the 7P marketing mix activities carried out by Okui Kopi 3.0 Surabaya on consumer purchase interest, to determine the effect of the $7 P$ marketing mix on consumer purchase interest, and to imply the results of research for Okui Kopi 3.0 Surabaya shop. The sampling method used was a non-probability sampling method with a purposive sampling technique. The number of samples in this study were 50 respondents. The data analysis technique used was the Structural Equation Model Partial Least Square (SEM PLS). The results of this study indicate that the variables of product, price, place, promotion, and people have a significant influence on consumer buying interest where the $p$-value is $\leq 0.05$. Meanwhile, process variables and physical evidence did not have a significant effect on consumer purchase interest because the p-value $>0.05$.
\end{abstract}

Keywords—: Marketing Mix; Consumer Purchase Interest; SEM-PLS; Okui Kopi 3.0 Surabaya.

\section{PENDAHULUAN}

Pendahuluan berisi (secara berurutan) latar belakang Kopi merupakan salah satu hasil komoditas perkebunan yang memiliki nilai ekonomis yang cukup tinggi diantara komoditas perkebunan lainnya dan berperan penting sebagai sumber devisa negara. Kopi merupakan komoditas tropis utama yang diperdagangkan di dunia, dengan kontribusi setengah dari total ekspor komoditas tropis lainnya. Kopi ialah salah satu jenis minuman yang disukai oleh sebagian besar gaya hidup masyarakat Indonesia khususnya di kota Surabaya (Rahardjo et al., 2020). Masyarakat Indonesia cenderung menghabiskan waktu luangnya di kafe favorit. Seiring dengan meningkatnya mobilitas dan gaya hidup khususnya dikota-kota besar Indonesia, pertumbuhan Coffee shop menjadi cukup pesat.

Pertumbuhan bisnis kedai kopi atau coffee shop yang sangat cepat mendorong perusahaan untuk mampu bersaing dalam setiap aktivitas pemasaran produk dan jasa. Kegiatan pemasaran memiliki peran yang sangat penting dalam kegiatan usaha, mengingat orientasinya dalam memberikan nilai kepada konsumen. Setiap pelaku usaha di tiap kategori bisnis dituntut untuk memiliki kepekaan terhadap setiap perubahan yang terjadi, apabila pelaku usaha tersebut tidak mengikuti perubahan yang terjadi maka akan berdampak pada keberlangsungan usahanya. Salah satunya perubahan yang terjadi di era modern sekarang yaitu menikmati kopi tidak hanya berdiam saja di rumah melainkan bisa di nikmati disebuah coffee shop, cafe, dan lain sebagainya.

Okui Kopi 3.0 Surabaya mempunyai ciri khas dengan konsep tempat (seperti rumah), konsep pelayanan, konsep jualan dan konsep menu yang fokus pada kopi nusantara. Okui Kopi 3.0 hadir dari tahun 2019. Pemilihan kedai Okui Kopi 3.0 sebagai obyek penelitian adalah dimana sudah cukup dikenal oleh kalangan pemuda pemudi di Kota Surabaya. Sejak awal berdirinya Okui Kopi 3.0 berusaha untuk memenuhi kegemaran dan kebutuhan sebagian orang dalam menikmati kopi. Okui Kopi 3.0 sering menyelenggarakan kegiatan-kegiatan yang melibatkan pihak internal maupun eksternal sembari melakukan kegiatan promosi dan menjalankan fungsi sosialnya terhadap lingkungan.

Bauran pemasaran adalah sekumpulan perlengkapan yang bisa dimanipulasi oleh organisasi ataupun industri buat menggapai tujuan baik dalam jangka pendek ataupun jangka panjang (Bahman et al., 2013). Bauran pemasaran juga merupakan kebijakan yang digunakan pada perusahaan untuk mampu memasarkan produknya dan mencapai keuntungan. Hal ini seperti yang disampaikan oleh Kotler (2003) adalah : "Marketing mix is the set of marketing tools that the firm uses to pursue it's marketing objectives in the target market”. Bauran pemasaran merupakan sekumpulan alat pemasaran (marketing mix) tersebut digunakan oleh perusahaan untuk mencapai tujuan pemasarannya dalam pasar sasaran. Adapun bauran pemasaran adalah : "Marketing mix defined as the elemens an organizations controls that can be used to satisfy or communicate with customer. These elements appear as core decisions variables in any marketing text or marketing plan”. Bauran pemasaran adalah elemen pada organisasi perusahan yang mengkontrol dalam melakukan komunikasi dengan konsumen atau dipakai untuk mencapai kepuasan 
Website : http://agritek.unmermadiun.ac.id/index.php/agritek

konsumen. Bauran pemasaran mengacu pada tujuh bidang utama pengambilan keputusan (7P) dalam proses pemasaran yang dicampur dan dicampur untuk mendapatkan hasil yang diinginkan oleh organisasi untuk memenuhi kebutuhan dan keinginan pelanggan. Ini adalah seperangkat alat pemasaran taktis yang dapat dikontrol dari produk, harga, tempat, promosi, proses, orang, dan bukti fisik (7P) yang merupakan variabel yang dapat dikontrol oleh manajer pemasaran untuk memenuhi kebutuhan pelanggan dengan sebaik-baiknya. Goi (2009) mengemukakan bahwa variabel pemasaran harus dibagi menjadi dua bagian yaitu penawaran (produk, kemasan, merek, harga dan layanan) dan metode dan alat (saluran distribusi, penjualan pribadi, periklanan, promosi penjualan dan publisitas).

Gunardi (2014) bahwa faktor produk tidak memiliki pengaruh signifikan terhadap minat beli sedangkan kedua faktor (bukti fisik dan harga) memiliki pengaruh signifikan dalam menimbulkan minat beli konsumen di My Kopi-O Surabaya. Menurut Ariani, S., et al (2017) bahwa variabel produk memiliki pengaruh signifikan terhadap kepuasan dan loyalitas pelanggan, sedangkan variabel harga, tempat, dan promosi tidak memiliki pengaruh signifikan dalam membentuk kepuasan dan loyalitas pelanggan. Amofah \& Gyamfi (2016), bahwa proses memiliki pengaruh terbesar terhadap keputusan pelanggan untuk mengulangi pembelian sedangkan atribut lainnya kecuali tempat secara signifikan mempengaruhi keputusan untuk membeli ulang. Souar et al (2015), bahwa produk, proses, dan promosi berpengaruh positif dan signifikan terhadap loyalitas pelanggan.

Tujuan dari penelitian ini adalah untuk menganalisis pengaruh bauran pemasaran (marketing mix) 7P terhadap minat beli konsumen di Okui Kopi 3.0 Surabaya.

\section{METODE PENELITIAN}

Penelitian ini merupakan studi kasus pada Kedai Kopi / Coffee Shop Okui Kopi 3.0 Surabaya, Jawa Timur. Lokasi penelitian berada di Jalan Bawean Nomer 37, Kel. Ngagel, Kec. Wonokromo, Kota Surabaya, Jawa Timur. Pemilihan lokasi ini berdasarkan pertimbangan bahwa Okui Kopi 3.0 adalah salah satu usaha dalam bidang perkopian yang memproduksi kopi siap saji dengan menggunakan bahan baku biji kopi. Objek pada penelitian ini adalah variabel independen yang terdiri dari Produk (X1), Harga (X2), Tempat (X3), Promosi (X4), Orang (X5), Proses (X6), dan Bukti Fisik (X7), serta variabel dependen yang berupa minat beli konsumen $(\mathrm{Y})$.

Sampel pada penelitian ini adalah konsumen Okui Kopi 3.0 Surabaya. Lalu, untuk pengisian kuisioner responden harus memenuhi beberapa kriteria yaitu konsumen yang sudah pernah mengunjungi kedai Okui Kopi 3.0 Surabaya. Kriteria tersebut diinginkan karena mempertimbangkan untuk dapat menjawab pertanyaan yang berkaitan dengan kedai Okui Kopi 3.0 Surabaya sehingga dapat memberi jawaban dengan benar dan akurat.

Penelitian ini menggunakan analisis SEM-PLS, maka besar sampel harus mengikuti aturan yang ada didalam SEM-PLS tersebut. Menurut Ghozali (2008) adapun aturan yang ada didalam SEM-PLS adalah apabila menggunakan alat analisis PLS, jumlah sampel minimal berkisar antara 30 sampai dengan 100 kasus. Sementara, menurut Kock (2018) jumlah minimal responden untuk dapat dianalisis dengan Warppls adalah sebesar 50 responden. Jumlah responden pada penelitian ini sebanyak 50 responden dapat dikatakan sudah memenuhi dari kriteria yang telah dijabarkan.

III.HASIL DAN PEMBAHASAN

\begin{tabular}{|c|c|c|c|c|c|c|}
\hline Hipotesis & $\begin{array}{c}\text { Path } \\
\text { Coefficients }\end{array}$ & $\begin{array}{c}\text { P- } \\
\text { Values }\end{array}$ & $\begin{array}{l}\text { Standart Error for } \\
\text { Path Coeffiecients }\end{array}$ & $\begin{array}{l}\text { Effect } \\
\text { Size }\end{array}$ & Kriteria & Kesimpulan \\
\hline $\begin{array}{l}\text { Produk }> \\
\text { Minat Beli } \\
\text { Konsumen }\end{array}$ & 0,260 & 0,024 & 0,128 & 0,168 & \multirow{7}{*}{$\begin{array}{c}\text { diterima } \\
\text { apabila } \\
\text { p-value } \leq \\
0,05 \\
\text { dan } \\
\text { ditolak } \\
\text { apabila } \\
\text { p-value }> \\
0,05\end{array}$} & $\begin{array}{l}\text { Hipotesis } \\
\text { Diterima }\end{array}$ \\
\hline $\begin{array}{l}\text { Harga > } \\
\text { Minat Beli } \\
\text { Konsumen }\end{array}$ & 0,439 & $<0,001$ & 0,119 & 0,148 & & $\begin{array}{l}\text { Hipotesis } \\
\text { Diterima }\end{array}$ \\
\hline $\begin{array}{l}\text { Tempat -> } \\
\text { Minat Beli } \\
\text { Konsumen }\end{array}$ & 0,226 & 0,044 & 0,130 & 0,133 & & $\begin{array}{l}\text { Hipotesis } \\
\text { Ditenima }\end{array}$ \\
\hline $\begin{array}{l}\text { Promosi > } \\
\text { Minat Beli } \\
\text { Konsumen }\end{array}$ & 0,400 & $<0,001$ & 0,121 & 0,211 & & $\begin{array}{l}\text { Hipotesis } \\
\text { Ditenima }\end{array}$ \\
\hline $\begin{array}{l}\text { Orang }> \\
\text { Minat Beli } \\
\text { Konsumen }\end{array}$ & 0,314 & 0,008 & 0,125 & 0,188 & & $\begin{array}{l}\text { Hipotesis } \\
\text { Diterima }\end{array}$ \\
\hline $\begin{array}{l}\text { Proses > } \\
\text { Minat Beli } \\
\text { Konsumen }\end{array}$ & 0,149 & 0,134 & 0,134 & 0,080 & & $\begin{array}{l}\text { Hipotesis } \\
\text { Ditolak }\end{array}$ \\
\hline $\begin{array}{l}\text { BuktiFisik- } \\
>\text { Minat Beli } \\
\text { Konsumen }\end{array}$ & $-0,069$ & 0,310 & 0,138 & 0,034 & & $\begin{array}{l}\text { Hipotesis } \\
\text { Ditolak }\end{array}$ \\
\hline
\end{tabular}

Gambar 1. Hasil Studi Berbasis Pengolahan Data WarpPLS 
Website : http://agritek.unmermadiun.ac.id/index.php/agritek

Variabel produk memiliki pengaruh yang signifikan terhadap minat beli konsumen Okui Kopi 3.0 Surabaya dapat dilihat dari nilai p-value sebesar 0,024 dimana nilai tersebut telah memenuhi kriteria diterimanya hipotesis yaitu $p$-value $\leq 0,05$. Produk juga memiliki pengaruh positif terhadap minat beli konsumen Okui Kopi 3.0 Surabaya karena memiliki nilai path coefficient yang positif yaitu sebanyak 0,260 . Nilai effect size variabel produk sebesar 0,168 yang berarti bahwa variabel produk mempengaruhi variabel minat beli konsumen Okui Kopi 3.0 Surabaya sebesar 16,8 persen dan sisanya dipengaruhi oleh variabel lain. Hal tersebut menunjukkan bahwa semakin positif persepsi konsumen terhadap indikator-indikator produk maka minat beli konsumen terhadap produk akan semakin meningkat. Okui Kopi 3.0 Surabaya telah menerapkan variabel produk dengan baik terbukti dari penilaian responden, Okui Kopi 3.0 Surabaya memiliki rasa yang enak (X1.4) yang menjadi indikator paling dominan karena rasa yang enak bisa jadi penentu konsumen dalam memilih mana yang ingin dibeli dan cocok untuk dikonsumsi oleh konsumen (Permatasari, et al, 2021).

Variabel harga memiliki pengaruh yang signifikan terhadap minat beli konsumen Okui Kopi 3.0 Surabaya dapat dilihat dari nilai p-value sebesar $<0,001$ dimana nilai tersebut telah memenuhi kriteria diterimanya hipotesis yaitu $\mathrm{p}$-value $\leq 0,05$. Harga juga memiliki pengaruh positif terhadap minat beli konsumen Okui Kopi 3.0 Surabaya karena memiliki nilai path coefficient yang positif yaitu sebanyak 0,439. Nilai effect size variabel harga sebesar 0,148 yang berarti bahwa variabel harga mempengaruhi variabel minat beli konsumen Okui Kopi 3.0 Surabaya sebesar 14,8 persen dan sisanya dipengaruhi oleh variabel lain. Hal tersebut menunjukkan bahwa semakin positif persepsi konsumen terhadap indikator-indikator harga maka minat beli konsumen terhadap harga akan semakin meningkat. Okui Kopi 3.0 Surabaya telah menerapkan variabel harga dengan baik terbukti dari penilaian responden, Okui Kopi 3.0 Surabaya memiliki daftar harga yang lengkap (X2.1) yang menjadi indikator paling dominan karena ketika konsumen hendak memesan minuman terdapat daftar harga yang lengkap.

Variabel tempat memiliki pengaruh yang signifikan terhadap minat beli konsumen Okui Kopi 3.0 Surabaya dapat dilihat dari nilai p-value sebesar 0,044 dimana nilai tersebut memenuhi kriteria diterimanya hipotesis yaitu $\mathrm{p}$-value $\leq 0,05$. Tempat juga memiliki pengaruh positif terhadap minat beli konsumen Okui Kopi 3.0 Surabaya memiliki nilai path coefficient dan effect size yang positif yakni masing-masing sebesar 0,226 dan 0,133. Dengan demikian dapat dikatakan bahwa peningkatan persepsi konsumen terhadap indikator-indikator tempat dapat menguatkan minat beli konsumen terhadap produk yang dijual. Okui Kopi 3.0 Surabaya telah menerapkan variabel tempat dengan baik terbukti dari penilaian responden, Okui Kopi 3.0 Surabaya tempat yang mudah dijangkau (X3.1) yang menjadi indikator paling dominan. Tempat menjadi salah satu faktor penentu keberhasilan suatu program pemasaran. Suatu lokasi disebut strategis bila terletak dipusat kota, kepadatan populasi, kemudahan mencapainya menyangkut kemudahan transportasi, dan lokasi yang dinilai mampu mengalami perkembangan ekonomi (Ekawanti, 2019).

Variabel promosi memiliki pengaruh yang signifikan terhadap minat beli konsumen Okui Kopi 3.0 Surabaya dapat dilihat dari nilai p-value sebesar $<0.001$ dimana nilai tersebut memenuhi kriteria diterimanya hipotesis yaitu p-value $\leq 0,05$. Promosi juga memiliki pengaruh positif terhadap minat beli konsumen Okui Kopi 3.0 Surabaya memiliki nilai path coefficient dan effect size yang positif yakni masing-masing sebesar 0,400 dan 0,211. Dengan demikian dapat dikatakan bahwa peningkatan persepsi konsumen terhadap indikator-indikator promosi dapat menguatkan minat beli konsumen terhadap produk yang dijual. Okui Kopi 3.0 Surabaya telah menerapkan variabel promosi dengan baik terbukti dari penilaian responden, Okui Kopi 3.0 Surabaya selalu menginformasikan melalui media sosial (X4.3) yang menjadi indikator paling dominan. Promosi menjadi salah satu faktor penentu keberhasilan suatu program pemasaran. Betapapun berkualitasnya suatu produk ramah lingkungan, bila konsumen belum pernah mendengarnya dan tidak yakin bahwa produk itu akan berguna bagi mereka, maka mereka tidak akan pernah membeli (Tjiptono 2008).

Variabel orang memiliki pengaruh yang signifikan terhadap minat beli konsumen Okui Kopi 3.0 Surabaya dapat dilihat dari nilai p-value sebesar 0,008 dimana nilai tersebut memenuhi kriteria diterimanya hipotesis yaitu $\mathrm{p}$-value $\leq 0,05$. Orang juga memiliki pengaruh positif terhadap minat beli konsumen Okui Kopi 3.0 Surabaya memiliki nilai path coefficient dan effect size yang positif yakni masing-masing sebesar 0,314 dan 0,188. Dengan demikian dapat dikatakan bahwa peningkatan persepsi konsumen terhadap indikator-indikator orang dapat menguatkan minat beli konsumen terhadap produk yang dijual. Okui Kopi 3.0 Surabaya telah menerapkan variabel orang dengan baik terbukti dari penilaian responden, Okui Kopi 3.0 Surabaya memiliki budaya karyawan atau ciri khas ketika memesan (X5.3) yang menjadi indikator paling dominan. Orang menjadi salah satu faktor penentu keberhasilan suatu program pemasaran. Ivy \& Naudé (2004) menyatakan bahwa orang adalah salah satu elemen yang sangat berpengaruh dalam minat beli konsumen.

Variabel proses tidak memiliki pengaruh yang signifikan terhadap minat beli konsumen Okui Kopi 3.0 Surabaya dapat dilihat dari nilai p-value sebesar 0,134 dimana nilai tersebut tidak memenuhi kriteria diterimanya hipotesis yaitu $p$-value $\leq 0,05$. Proses tidak memiliki pengaruh positif terhadap minat beli konsumen Okui Kopi 3.0 Surabaya memiliki nilai path coefficient sebesar 0149 dan memiliki pengaruh positif karena memiliki nilai effect size yakni sebesar 0,080. Dengan demikian dapat dikatakan bahwa peningkatan persepsi konsumen terhadap indikator-indikator proses dapat menguatkan minat beli konsumen terhadap produk yang dijual. Okui Kopi 3.0 Surabaya telah menerapkan variabel proses dengan baik terbukti dari penilaian responden, Okui Kopi 3.0 Surabaya memiliki pengolahan produk yang baik(X6.3) yang menjadi indikator paling dominan. Proses menjadi salah satu faktor penentu keberhasilan suatu program pemasaran. Proses mengacu pada praktik terbaik dalam memberikan produk serta layanan kepada pembeli dengan tujuan membuat mereka senang dan puas (Hashim \& Hamzah, 2014). 
Website : http://agritek.unmermadiun.ac.id/index.php/agritek

Variabel bukti fisik tidak memiliki pengaruh yang signifikan terhadap minat beli konsumen Okui Kopi 3.0 Surabaya dapat dilihat dari nilai p-value sebesar 0,310 dimana nilai tersebut tidak memenuhi kriteria diterimanya hipotesis yaitu p-value $\leq 0,05$. Namun, bukti fisik juga memiliki pengaruh positif terhadap minat beli konsumen Okui Kopi 3.0 Surabaya karena memiliki nilai path coefficient yang negatif yaitu sebanyak -0,069. Nilai effect size sebesar 0,034 . Hal tersebut menunjukkan bahwa semakin positif persepsi konsumen terhadap indikator-indikator bukti fisik maka minat beli konsumen terhadap harga akan semakin meningkat. Okui Kopi 3.0 Surabaya telah menerapkan variabel bukti fisik dengan baik terbukti dari penilaian responden, Okui Kopi 3.0 Surabaya memiliki standar lingkungan atau kebersihan yang baik (X7.1) yang menjadi indikator paling dominan karena menurut Akroush (2011) mengemukakan bahwa bukti fisik adalah semua elemen yang berwujud yang memberikan suasana yang bersahabat di lingkungan layanan.

\section{IV.KESIMPULAN}

Berdasarkan hasil penelitian dapat disimpulkan bahwa Okui Kopi 3.0 Surabaya sudah menerapkan konsep bauran pemasaran (marketing mix) dengan baik. Pada variabel produk, harga, tempat, promosi, dan orang memiliki pengaruh yang signifikan terhadap minat beli konsumen Okui Kopi 3.0 Surabaya. Sedangkan pada variabel proses dan bukti fisik tidak memiliki pengaruh yang signifikan terhadap minat beli konsumen Okui Kopi 3.0 Surabaya. Namun peningkatan persepsi konsumen terhadap indikator proses dan bukti fisik masih dianggap dapat menguatkan minat beli konsumen terhadap produk yang dijual. Hal tersebut dapat memotivasi para pelaku usaha kedai kopi untuk dapat merancang dan menerapkan strategi yang tepat agar selalu dapat meningkatkan volume penjualan, pangsa pasar, dan minat beli konsumen.

\section{UCAPAN TERIMAKASIH}

Terimakasih kepada pihak manajemen Okui Kopi 3.0 Surabaya yang telah memberi izin untuk melakukan penelitian ini, serta terimakasih kepada keluarga atas doa dan dukungannya.

\section{VI.DAFTAR PUSTAKA}

Akroush, M. N. 2011. The 7Ps Classification of the Services Marketing Mix Revisited: An Empirical Assessment of their Generalisability , Applicability and Effect on Performance - Evidence from Jordan's Services Organisations. Jordan Journal of Business Administration, 7(1) : 116-147.

Amofah, O., \& Gyamfi, I. 2016. The Influence of Service Marketing Mix on Customer Choice of Repeat Purchase of Restaurant in Kumasi , Ghana. European Journal of Business and Management, 8(11): 102-112.

Ariani, S., Suharno, dan A. F. 2017. Bauran Pemasaran Kepuasan Dan Loyalitas Pelanggan Benih Kelapa Sawit Pt Socfin Indonesia. Jurnal Manajemen (e-JM), 21(11) : 71-89.

Bahman, S. P., Kamran, N., \& Mostafa, E. 2013. The effect of marketing mix in attracting customers: Case study of Saderat Bank in Kermanshah Province. African Journal of Business Management, 7(34) : 3272-3280.

Ekawanti, U. 2019. Pengaruh Lokasi Toko Dan Promosi Terhadap Minat Beli Konsumen Pada Distro Jenawi Oblong Riau Pekanbaru. Journal of Manajement, $6(2): 1-15$.

Ghozali, I. 2008. Structural Equation Modelling. Edisi Kedua. Semarang: Badan Penerbit Universitas Diponegoro.

Goi, C. L. 2009. A Review of Marketing Mix: 4Ps or More? International Journal of Marketing Studies, 1(1): 2-15.

Gunardi, F. dan A. S. 2014. Analisa Pengaruh Produk, Bukti Fisik, Dan Harga Terhadap Minat Beli Konsumen Di My Kopi-O Surabaya. Jurnal Hospitality Dan Manajemen Jasa, 2(1) : 1-11.

Hashim, N., \& Hamzah, M. I. 2014. 7P' s : A Literature Review of Islamic Marketing and Contemporary Marketing Mix. Procedia - Social and Behavioral Sciences, $130: 155-159$

Ivy, J., \& Naudé, P. 2004. Succeeding in the MBA marketplace: Identifying the underlying factors. Journal of Higher Education Policy and Management, 26(3) : 401-417.

Kock, Ned. 2018. WarpPLS User Manual: Version 6.0. Texas: ScriptWarp Systems.

Kotler, P. 2003. Marketing Management with Brand Management. Jakarta : Prenhallindo.

Permatasari, I. I. Nurdiana, dan A. S. 2021. Pengaruh Produk , Harga dan Promosi Terhadap Keputusan Pembelian Pada Toko Joyshop Malang. Jurnal Riset Mahasiswa Manajemen (JRMM), 6(2): 1-5.

Rahardjo, B., Akbar, B. M. B., Iskandar, Y., \& Shalehah, A. 2020. Analysis and strategy for improving Indonesian coffee competitiveness in the international market. BISMA (Bisnis Dan Manajemen), 12(2) : 154-167.

Souar, Y., Mahi, K., \& Ameur, I. 2015. The Impact of Marketing Mix Elements on Customer Loyalty for an Algerian Telecommunication Company. Expert Journal of Marketing, 3(1) : 1-10.

Tjiptono, F. 2008. Strategi Pemasaran. Edisi ke 3. Yogyakarta: Andi Offset. 